\title{
Bacterial blight on Dracaena sanderiana caused by Burkholderia cepacia
}

\author{
Okhee $\mathrm{Choi}^{1} \cdot$ Yeyeong Lee ${ }^{2} \cdot$ Byeongsam Kang ${ }^{3} \cdot$ Seunghoe $\mathrm{Kim}^{2} \cdot$ Jinwoo Kim ${ }^{1,2,3}$ (D)
}

Received: 12 June 2019 / Accepted: 7 January 2020 / Published online: 10 January 2020

(C) Australasian Plant Pathology Society Inc. 2020

\begin{abstract}
In 2018, severe bacterial blight was observed on Dracaena sanderiana plants imported and cultivated by a commercial nursery in Jinju, South Korea. This indoor plant is popularly grown for indoor air purification to prevent sick building syndrome (SBS). The diseased plants had severe blight symptoms, with leaf chlorosis and crumpling of stem and leaves. To identify the causal agent, we performed bacterial isolation, pathogenicity tests, physiological analysis, sequencing of the 16S rRNA region and recA gene, and phylogenetic analysis; the bacterial pathogen was identified as Burkholderia cepacia. This is the first report of bacterial blight on $D$. sanderiana caused by B. cepacia. Although there is no clear epidemiological information on the inoculum source, the recent occurrence of the disease indicates that $B$. cepacia is a potential threat to the production of indoor dracaena plants, which are increasingly used for air purification in SBS. Because $D$. sanderiana is grown in indoor living spaces, $B$. cepacia infection could threaten human health as well.
\end{abstract}

Keywords Dracaena sanderiana $\cdot$ Blight $\cdot$ Burkholderia cepacia $\cdot 16 \mathrm{~S}$ rRNA $\cdot$ recA

Dracaena sanderiana, also called 'Lucky Bamboo' or 'Ribbon Dracaena', is a flowering plant in the family Asparagaceae. It is a small, shrubby plant with slim stems and flexible strap-shaped leaves. D. sanderiana is native to Cameroon in tropical West Africa, where it grows on the ground in tropical rainforests (Damen et al. 2018). It is a popular indoor plant that can survive in various indoor environments and has many cultivars (USDA, ARS 2008; Damen et al. 2018). D. sanderiana is often propagated from short cuttings in water. In Korea, it is called lucky bamboo because it is believed to bring happiness and prosperity when it is grown in houses and workplaces; this belief has made it more popular. Although it is attracting attention as an air purification plant to eliminate sick building syndrome (SBS), which is becoming a serious problem (Orwell et al. 2006; Dela Cruz

Okhee Choi and Yeyeong Lee contributed equally to this work.

Jinwoo Kim

jinwoo@gnu.ac.kr

1 Institute of Agriculture and Life Science, Gyeongsang National University, Jinju 52828, South Korea

2 Department of Plant Medicine, Gyeongsang National University, Jinju 52828, South Korea

3 Division of Applied Life Science, Gyeongsang National University, Jinju, South Korea et al. 2014), there are no accurate data on imports into South Korea.

In 2018, bacterial blight was observed on D. sanderiana that was grown commercially in a nursery in Jinju, South Korea. The diseased $D$. sanderiana had severe symptoms of blight and leaf chlorosis (Fig. 1). Since D. sanderiana is a recently imported plant, no diseases have been reported in South Korea; however, bacterial leaf spot caused by Xanthomonas campestris, and Stewart's wilt caused by Pantoea stewartii, have been recorded in Korea (Korean Society of Plant Pathology 2009; Choi and Kim 2013).

In this study, we isolated and identified the causal plant pathogen from wilted $D$. sanderiana plants. We performed bacterial isolation, pathogenicity tests, molecular identification, and physiological tests. Here, we report the occurrence of bacterial blight caused by Burkholderia cepacia on $D$. sanderiana for the first time. The occurrence of this disease indicates that $B$. cepacia poses a potential risk to the production of ornamental D. sanderiana plants.

Bacteria were isolated as described previously (Choi and Kim 2013) with some modifications. Tissues $(\times 5 \mathrm{~mm})$ from wilted stems of plants with leaf chlorosis were added to a 1.5$\mathrm{ml}$ microtube containing $0.5 \mathrm{ml}$ of sterile distilled water, macerated with a pipette tip, left to soak for $10 \mathrm{~min}$, and vortexed vigorously to make a suspension. A $100 \mu \mathrm{l}$ aliquot of a 1/10 serial dilution was spread on 1/10 tryptic soy broth agar 
Fig. 1 Natural occurrence of bacterial blight and leaf chlorosis caused by Burkholderia cepacia on Dracaena sanderiana. a Blight; b leaf chlorosis
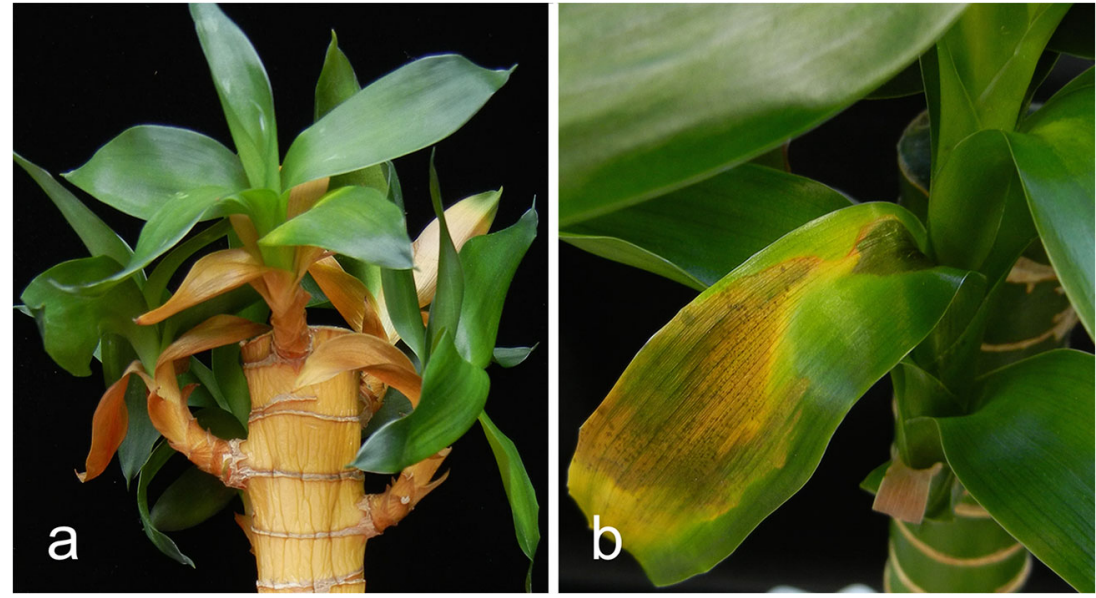

(TSBA) and incubated at $28^{\circ} \mathrm{C}$ for 3 days. The resulting dominant colonies were streaked onto new TSBA. Gram-negative, rod-shaped, and non-spore forming yellow colonies of bacteria were consistently isolated from infected tissues on TSBA. The yellow colonies were circular and opaque with smooth margins, and produced non-fluorescent yellow pigment. A representative isolate was deposited in the Korean Agricultural Culture Collection (KACC 21282).

Pathogenicity tests were performed as described previously (Choi and Kim 2013) with some modifications. Three bacterial isolates including KACC 21282 were cultured on TSBA for 2 days. Bacterial suspensions $\left(\sim 10^{8} \mathrm{CFU} / \mathrm{ml}\right)$ in sterile distilled water were inoculated on the stems and leaves of D. sanderiana purchased from nurseries using the syringe infiltration method. The inoculated plants were kept in a greenhouse at $25^{\circ} \mathrm{C}$ for 10 days. Sterile distilled water was used as a negative control. The stems and leaves of $D$. sanderiana inoculated with the bacterial isolates showed the typical symptoms of blight (Fig. 2a) and leaf chlorosis (Fig. 2b), whereas those infiltrated with sterile distilled water showed no symptoms after 10 days. Koch's postulates were fulfilled as the $16 \mathrm{~S}$ rRNA gene sequence was identical for bacterial isolates with confirmed pathogenicity.

Three isolates including KACC 21282 were tested for the tobacco leaf hypersensitive reaction and potato rot induction. All bacterial isolates were negative in the potato rot assays; however, they induced a hypersensitive reaction in tobacco leaves.

The physiological and biochemical characteristics of the bacteria were determined using the API 20NE system (BioMérieux, Marcy l'Etoile, France). The optical density of the bacterial suspension was adjusted as recommended by the manufacturer. In biochemical tests, KACC 21282 utilized Dglucose, L-arabinose, D-mannose, D-mannitol, N-acetyl-glucosamine, potassium gluconate, caprate, adipate, malate, trisodium citrate, and phenyl acetate, while it did not utilize $\mathrm{D}$-maltose. The isolate was positive for catalase, oxidase, $\beta$ glucosidase, protease, and $\beta$-galactosidase, but negative for the production of arginine dihydrolase, urease, and indole. The isolate did not reduce nitrates to nitrites.

To confirm the identity of the bacteria, the $16 \mathrm{~S}$ rRNA and recA genes were amplified with primer pairs $27 \mathrm{mF}\left(5^{\prime}\right.$ AGAGTTTGATCMTGGCTCAG-3') and 1492mR (5'GGYTACCTTGTTACGACTT-3') and BCR1 (5'TGACCGCCGAGAAGAGCAA-3') and BCR2 (5'CTCTTCTTCGTCCATCGCCTC-3'), respectively (Lane 1991; Mahenthiralingam et al. 2000). DNA extraction and PCR amplification were as described previously (Choi et al. 2019). PCR was performed on a thermal cycler (T100; BioRad, Hercules, CA, USA) using PCR premix (Bioneer, Daejeon, Korea), $1 \mu$ genomic DNA, and $1 \mathrm{mM}$ each primer, under the following conditions: $98^{\circ} \mathrm{C}$ for $2 \mathrm{~min}$; 30 cycles of $98^{\circ} \mathrm{C}$ for $30 \mathrm{~s}, 55^{\circ} \mathrm{C}$ for $30 \mathrm{~s}$, and $70{ }^{\circ} \mathrm{C}$ for $1 \mathrm{~min}$; and a final 4-min extension at $72{ }^{\circ} \mathrm{C}$. The PCR products were examined by electrophoresis in $0.8 \%$ agarose gels, purified using Expin Gel SV (GeneAll Biotechnology, Seoul, Korea) and cloned using pGEM-T Easy Vector (Promega, Madison, WI, USA), according to the manufacturers' instructions. Sequencing was performed with primers M13F and M13R using a BigDye Terminator Cycle Sequencing kit (Applied Biosystems, Foster City, CA, USA), following the manufacturer's instructions. Using BLAST, searches revealed that the 16S rRNA (1,495 bp; GenBank accession no. MK779204) and recA gene (1,040 bp; MK779203) sequences of KACC 21282 shared 99.87 and $99.9 \%$ similarity with $B$. cepacia SE-1 (KF681774) (Zhu et al. 2016) and ATCC17759 (AF143788) (Mahenthiralingam et al. 2000; Mahenthiralingam and Vandamme 2005), respectively.

The DNA sequences (MK779203 and MK779204) were analysed using the program BLAST and compared using the NCBI/GenBank database (http://www.ncbi.nlm.nih.gov/ blast/). A phylogenetic tree was generated using MEGA 4.0 with the neighbor joining method and Tajima-Nei distance model (Tamura et al. 2007). The sequences of related bacterial strains were downloaded from the GenBank database. A phylogenetic tree was constructed using partial recA sequences 
Fig. 2 Pathogenicity of Burkholderia cepacia causing bacterial blight on Dracaena sanderiana. a Symptoms developed after artificial inoculation on the stem of D. sanderiana (right) and a negative control inoculated with water (left); b leaf chlorosis after artificial inoculation on a

D. sanderiana leaf (right) and a negative control inoculated with water (left); $\mathbf{c}$ pathogenicity of B. cepacia on onion bulb
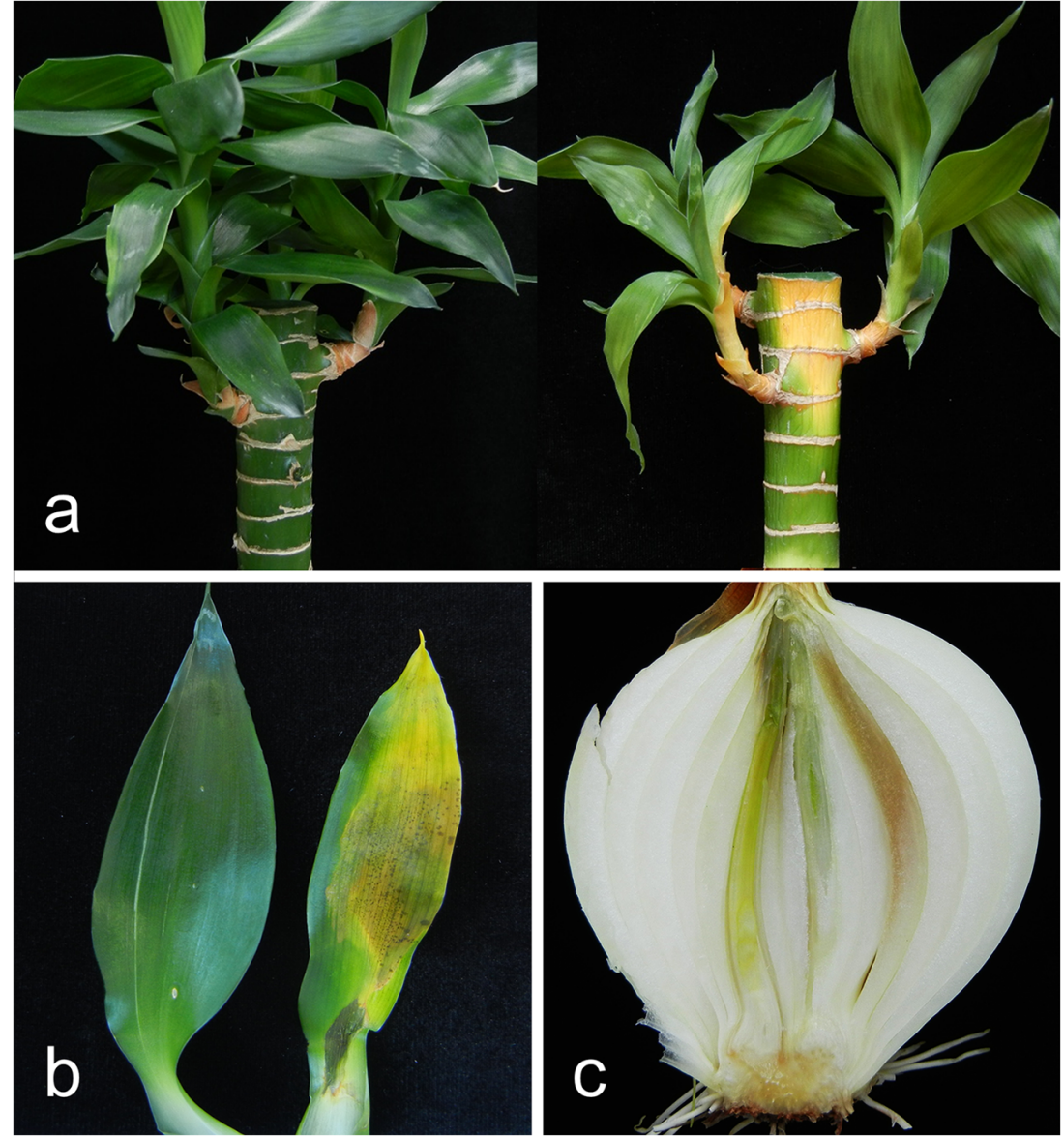

against the database of type strains of $B$. cepacia complex (Jacobs et al. 2008). These results confirmed that KACC 21282 from $D$. sanderiana was in the same cluster as $B$. cepacia (Fig. 3).
B. cepacia is reported to cause onion rot, and we also performed a pathogenicity test on onion bulbs. For onion bulb pathogenicity tests, three onion bulbs purchased from a market were each surface-disinfested with $70 \%$ ethanol, dried, and
Fig. 3 Phylogenetic tree produced from recA gene sequences showing the phylogenetic relationships among Burkholderia spp. using the neighbor-joining method. DNA sequences from the NCBI nucleotide database were aligned using ClustalW. The numbers above the branches are the bootstrap values. The isolate infecting Dracaena sanderiana is in bold

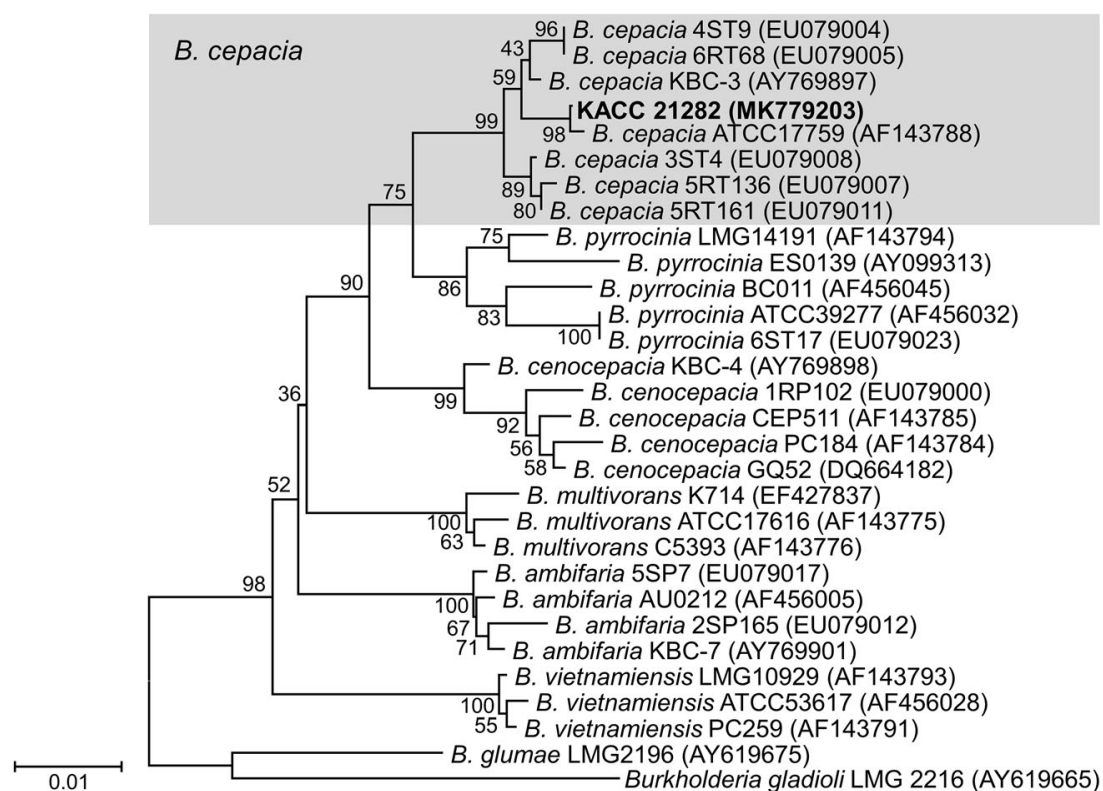


injected with $200 \mu \mathrm{l}$ of bacterial suspension $\left(\sim 10^{8} \mathrm{CFU} / \mathrm{ml}\right)$ of KACC 21282 using syringe infiltration. The bulbs were placed in plastic boxes at $100 \%$ relative humidity and incubated at room temperature for 7 days. Sterile distilled water was used as a negative control inoculation. KACC 21282 caused soft rot on the onion bulbs after 7 days after inoculation (Fig. 2c).

Combining the symptoms and results of the pathogenicity assay, API tests, and $16 \mathrm{~S}$ rRNA and recA gene sequencing, the pathogen causing blight on $D$. sanderiana was identified as $B$. cepacia. This is the first report that $B$. cepacia causes blight on indoor $D$. sanderiana.

Isolates of the $B$. cepacia complex often cause pneumonia in immunocompromised patients with underlying lung diseases such as cystic fibrosis and chronic granulomatous diseases (Isles et al. 1984; Mahenthiralingam and Vandamme 2005). Some isolates cause bacterial soft rot on onions, while others are biological control agents with potential agricultural benefits (Parke and Gurian-Sherman 2001; Sotokawa and Takikawa 2004). The bacterium occurs naturally in various environments, including soil, the rhizosphere, urban habitats, and river water (Miller et al. 2002; Dalmastri et al. 2003; Ramette et al. 2005). Because $D$. sanderiana plant is grown in indoor living spaces, $B$. cepacia infection could pose a risk to human health. Although epidemiological information on the inoculum source is unclear, the recent occurrence of the disease indicates that $B$. cepacia is a potential threat to the production of indoor plants, which are increasingly used for air purification, such as in SBS.

Acknowledgements This research was supported by Basic Science Research Program through the National Research Foundation of Korea (NRF) funded by the Ministry of Education of the Republic of Korea [2015R1A6A1A03031413].

\section{References}

Choi O, Kim J (2013) Pantoea stewartii causing stewart's wilt on Dracaena sanderiana in Korea. J Phytopathol 161:578-581

Choi O, Lee Y, Kang B, Bae J, Kim S, Kim J (2019) Aversion center blackening of muskmelon fruit caused by Pseudomonas oryzihabitans, an opportunistic pathogen of humans and warmblooded animals. Int J Food Microbiol 291:1-4

Dalmastri C, Fiore A, Alisi C, Bevivino A, Tabacchioni S, Giuliano G, Sprocati AR, Segre L, Mahenthiralingam E, Chiarini L, Vandamme
P (2003) A rhizospheric Burkholderia cepacia complex population: genotypic and phenotypic diversity of Burkholderia cenocepacia and Burkholderia ambifaria. FEMS Microbiol Ecol 46:179-187

Damen THJ, van der Burg WJ, Wiland-Szymańska J, Sosef MSM (2018) Taxonomic novelties in African Dracaena (Dracaenaceae). Blumea 63:31-53

Dela Cruz M, Müller R, Svensmark B, Pedersen JS, Christensen JH (2014) Assessment of volatile organic compound removal by indoor plants-a novel experimental setup. Environ Sci Pollut Res Int 21: 7838-7846

Isles AL, Maclusky I, Corey M, Gold R, Prober C, Fleming P, Levison H (1984) Pseudomonas cepacia infection in cystic fibrosis: an emerging problem. J Pediatr 104:206-210

Jacobs JL, Fasi AC, Ramette A, Smith JJ, Hammerschmidt R, Sundin GW (2008) Identification and onion pathogenicity of Burkholderia cepacia complex isolates from the onion rhizosphere and onion field soil. Appl Environ Microbiol 74:3121-3129

Korean Society of Plant Pathology (2009) List of plant diseases in Korea, 5th ed. 853. Anyang, Korea: JY Press

Lane DJ (1991) 16S/23S rRNA sequencing. In: Stackebrandt E, Goodfellow M (eds) Nucleic acid techniques in bacterial systematics. John Wiley \& Sons, New York, pp 155-147

Mahenthiralingam E, Bischof J, Byrne SK, Radomski C, Davies JE, AvGay Y, Vandamme P (2000) DNA-based diagnostic approaches for identification of Burkholderia cepacia complex, Burkholderia vietnamiensis, Burkholderia multivorans, Burkholderia stabilis, and Burkholderia cepacia genomovars I and III. J Clin Microbiol 38:3165-3173

Mahenthiralingam E, Vandamme P (2005) Taxonomy and pathogenesis of the Burkholderia cepacia complex. Chron Respir Dis 2:209-217

Miller SCM, LiPuma JJ, Parke JL (2002) Culture-based and non-growthdependent detection of the Burkholderia cepacia complex in soil environments. Appl Environ Microbiol 68:3750-3758

Orwell RL, Wood RA, Burchett MD, Tarran J, Torpy F (2006) The potted-plant microcosm substantially reduces indoor air VOC pollution: II. Laboratory study. Water Air Soil Pollut 177:59-80

Parke JL, Gurian-Sherman D (2001) Diversity of the Burkholderia cepacia complex and implications for risk assessment of biological control strains. Annu Rev Phytopathol 39:225-258

Ramette A, LiPuma JJ, Tiedje JM (2005) Species abundance and diversity of Burkholderia cepacia complex in the environment. Appl Environ Microbiol 71:1193-1201

Sotokawa N, Takikawa Y (2004) Occurrence of bacterial rot of onion bulbs caused by Burkholderia cepacia in Japan. J Gen Plant Pathol 70:348-352

Tamura K, Dudley J, Nei M, Kumar S (2007) MEGA4: molecular evolutionary genetics analysis (MEGA) software version 4.0. Mol Biol Evol 24:1596-1599

USDA, ARS (2008) Dracaena sanderiana information from NPGS/GRIN. Internet Resource: http://www.ars-grin.gov/cgi-bin/ npgs/html/taxon.pl?449327 (verified Dec 05, 2012)

Zhu X, Pang C, Cao Y, Fan D (2016) Biotransformation of cholesterol and $16 \alpha, 17 \alpha$-epoxypregnenolone and isolation of hydroxylase in Burkholderia cepacia SE-1. Biomed Res Int 2016:5727631 